\title{
INFLASI DALAM PRESPEKTIF ISLAM (ANALISIS TERHADAP PEMIKIRAN AL-MAQRIZI)
}

\author{
Awaluddin \\ Jurusan Perbankan Syariah STAI Solok Nan Indah \\ Jl. Adinegoro No. 59 By Pass KTK Kota Solok \\ e-mail: aawal65@yahoo.com
}

\begin{abstract}
Inflation is one of the macroeconomic symptoms associated with the decline in exchange rates (money) on goods and services market. One of the leaders of Islamic economics who specializes in his discussion of macroeconomics is al-Maqrizi. The solution offered by al-Maqrizi related to the problems that occurred in Egypt is to use the natural monetary system, the dinar and dirbam become the base currency, while the fulus is published in a limited and only to buy trivial goods. Al-Maqrizi set the relative price for dinar, dirbam and fulus. The relative price of dinar and dirham is 1:24, while the relative price between dirbam and fulus is 1: 140. In addition to providing solutions to address the above three issues, al-Maqrizi also proposed solutions in a social perspective. This gives the conclusion that the impact of the economic crisis depends on the nature of income and wealth of each group. If the income is fixed or inflated but lower than the rate of inflation, then the condition is severe. Conversely, if their income rises higher than the rate of inflation, then their material welfare increases. Likewise with wealth in the form of money, they suffered losses because their purchasing power continued to decrease and they also had to increase the cost to meet the demands of the ever-increasing need.
\end{abstract}

Kata kunci: inflasi, perspektif Islam, pemikiran, Al-Maqrizi

\section{PENDAHULUAN}

7nflasi di dunia ekonomi modern sangat memberatkan masyarakat. Hal ini dikarenakan inflasi dapat mengakibatkan lemahnya efisiensi dan produktifitas ekonomi investasi, kenaikan biaya modal, dan ketidakjelasan ongkos serta pendapatan di masa yang akan datang. Keberadaan permasalahan inflasi dan tidak stabilnya sektor riil dari waktu ke waktu senantiasa menjadi perhatian sebuah rezim pemerintahan yang berkuasa serta otoritas moneter. Lebih dari itu, ada kecendrungan inflasi dipandang sebagai permasalahan yang senantiasa akan terjadi. Hal ini tercermin dari kebijakan otoritas moneter dalam menjaga tingkat inflasi. Setiap tahunnya otoritas moneter senantiasa menargetkan bahwa angka atau tingkat inflasi harus diturunkan menjadi satu digit atau inflasi moderat. Pengaruh inflasi cukup besar pada kehidupan ekonomi, inflasi merupakan salah satu masalah ekonomi yang banyak mendapat perhatian para ekonom, pemerintah, maupun masyarakat umum. Berbagai teori, pendekatan dan kebijakan dikembangkan supaya inflasi dapat dikendalikan sesuai dengan yang diinginkan. Pada makalah ini akan kami akan membahas mengenai "Inflasi".

Inflasi (Inflation) adalah gejala yang menunjukkan kenaikkan tingkat harga umum yang berlangsung terus menerus. 
Kenaikkan harga tersebut dimaksudkan bukan terjadi untuk sesaat. Dari pengertian tersebut maka apabila terjadi kenaikan harga hanya bersifat sementara, tidak dapat dikatakan inflasi. Misalnya harga barang-barang naik menjelang lebaran atau hari libur lainnya.Karena ketika lebaran usai harga barang kembali ke kondisi semula, maka harga seperti itu tidak dianggap sebagai inflasi. Inflasi juga berkaitan dengan kenaikkan harga secara umum,artinya kenaikakan harga satu jenis barang maupun jasa juga tidak termasuk inflasi, misalnya pada musim lebaran harga tiket pesawat naik. (Rozalinda, 2014: 298) Inflasi dianggap sebagai fenomena moneter, karna terjadinya penurunan nilai unit penghitungan moneter terhadap suatu komoditas. Campbell R. Mc Connell dan Stanley L Brue mengemukakan, inflasi adalah "a rise in the general level of prices".

Taqyuddin Ahmad Ibn Al-Maqrizi (1364-1441) Menyatakan, Seperti yang dikutip Euis Amalia dalam bukunya Sejarah Pemikiran Ekonomi Islam dari Masa Klasik hingga Kontemporer, bahwa Inflasi terjadi ketika harga secara umum mengalami kenaikkan yang berlangsung secara terus-menerus. Pada saat itu, persediaan barang dan jasa mengalami kelanggkaan,sementara konsumen harus mengeluarkan lebih banyak uang untuk sejumlah barang dan jasa yang sama (Amalia, 2005: 224). Menurut sukirno (2004:333) inflasi yaitu kenaikkan dalam harga barang dan jasa yang terjadi karena permintaan bertambah lebih besar dibandingkan dengan penawaran barang di pasar.Dengan kata lain, terlalu banyak uang yang memburu barang yang terlalu sedikit (Sukirno, 2008: p).

\section{TEORI INFLASI KONVENSIONAL}

Secara umum inflasi berarti kenaikkan tingkat harga secara umum dari barang atau, komoditas dan jasa selama suatu periode waktu tertentu. inflasi dapat dianggap sebagai fenomena moneter karna terjadinya penurunan nilai unit penghitungan moneter terhadap suatu komoditas. Definisi Inflasi oleh para Ekonom Modern adalah kenaikan yang menyeluruh dari jumlah uang yang harus dibayarkan (nilai unit penghitungan Moneter) terhadap barang-barang atau komoditas dan jasa. Sebaliknya, Jika yang terjadi adalah penurunan nilai unit penghitungan moneter terhadap barang barang atau komoditas dan jasa didefinisiakan sebagai deflasi (deflation).

Inflasi dapat diukur dengan tingkat inflasi (rate of inflation) yaitu tingkat perubahan dari tingkat harga secara umum. Persamaanya adalah Sebagai berikut:

Tingkat Harga (t) - Tingkat Harga (t-1) X100 Tingkat Harga $(\mathrm{t}-1)$

$=$ Rate of inflation

Contoh soal:

Cara menghitung laju inflasi (Murni, 2006: p)

Pada sebuah tabel menunjukkan suatu kelompok transport, komunikasi dan jasa keuangan pada bulan Oktober 2015 mencatat inflasi 28,57\%. Terjadi kenaikan indeks dari 127,91 pada September 2015 menjadi 164,45 pada bulan Oktober 2015. Dikatakan pada berita tersebut terjadi inflasi sebesar 28,57\% dari bulan September 2015 sampai Oktober 2015. Bagaimana menghitung angka $28,57 \%$ ? 
Jawab:

$$
\begin{aligned}
& \text { Inflasi }=\{(164,45-127,92) / 127,91\} \times 100 \% \\
& \text { Inflasi }=28,57 \%
\end{aligned}
$$

Umumnya, otoritas yang bertanggung jawab dalam mencatat statistik perekonomian suatu negara menggunakan 'consumer price indeks' atau CPI dan 'producer price index' atau PPI sebagai pengukur tingkat inflasi.Hanya saja kedua metode pengukuran tersebut memunyai kelemahan-kelemahan, yang salah satunya adalah menggunakan kumpulan yang mewakili sebuah subset dari seluruh barang dan jasa yang diproduksi keseluruhan perekonomian, sehingga indeks harga tersebut tidak merefleksikan secara akurat seluruh perubahan harga yang terjadi. Selain itu, CPI dan PPI juga kurang dapat mengakomodasi barang dan jasa yang baru diciptakan walaupun kelompok sukset barang dan jasa yang dipakai sebagai pengukur pada CPI dan PPI tersebut selalu direvisi dari waktu ke waktu. Para ekonom cenderung lebih senang menggunakan 'implicit gross domestic product deflator' atau GDP deflator untuk melakukan pengukuran tingkat inflasi. GDP deflator adalah rata rata harga dari seluruh barang tertimbang dengan kuantitas barang-barang tersebut yang betul-betul dibeli. Penghitungan dari GDP deflator ini sangat sederhana. Persamaannya adalah sebagai berikut:

Implicit price Deflator $=\underline{\text { Nominal GDP }} \times 100$ Real GDP

Contoh soal:

Cara menghitung IHK
Harga untuk barang tertentu pada tahun 2015 Rp.10.000,00 per unit, sedangkan harga pada tahun dasar Rp.8.000,00 per unit. Maka indeks hargapada tahun 2015 dapat dihitung sebagai berikut:

$\mathrm{IHK}=(\mathrm{Pn} / \mathrm{Po}) \times 100$

$\mathrm{IHK}=(\operatorname{Rp} 10.000 / \operatorname{Rp} 8.000) \times 100=125$

Ini berarti pada tahun 2015 telah terjadi kenaikan harga sebesar 25\% dari harga dasar yaitu 125-100 (sebagai tahun dasar).

Untuk dapat mengerti bagaimana inflasi, perlu dipahami bahwa uang mempunyai fungsi- fungsi sebagai berikut dalam perekonomian :

1. Media Pertukaran

2. Pengukuran Nilai

3. Unit Perhitungan dan Akuntansi

4. Penyimpan Nilai

5. Instrumen terms of Payment

Sedangkan motif orang menyimpan uang adalah :

1. Trancaktionary motive

2. Precautionary motive

3. Speculative (investment) motive (Budiono, 2005: $p$ )

\section{JENIS-JENIS INFLASI}

Jika dilihat dalam teori Inflasi dalam ilmu ekonomi konvensional dapat digolongkan dalam beberapa cara :

1. Inflasi dapat digolongkan menurut besarnya, yaitu:

a. Infasi Ringan (Low inflation)

Yang dimaksud inflasi satu digit (single digit inflation) yaitu dibawah $10 \%$ per tahun.Tingkat inflasi yang 
berkisar antara 2 sampai $4 \quad \%$ dikatakan tingkat inflasi yang rendah

b. Inflasi Sedang (Galooping Inflation atau Double digit bahkan triple digit inflation)

Yaitu inflasi antara 20\% sampai 200\% per tahun. Inflasi seperti ini terjadi karena pemerintah lemah, perang, revolusi, dan kejadian lain yang menyebabkan barang tidak tersedia sementara uang berlimpah sehingga orang tidak percaya pada uang.

c. Hyperinflation

Yaitu Inflasi diatas 200\% per tahun. Dalam keadaan seperti ini, orang tidak percaya pada uang. Lebih baik membelanjakan uang dan menyimpan dalam bentuk barang, seperti emas, tanah, dan bangunan karena barang -barang jenis ini kenaikan harganya setara dengan inflasi.

2. Berdasarkan Sumber Inflasi, Inflasi terbagi kepada :

a. Inflasi karena tarikan Permintaan (Demand Full Inflation)

Yaitu kenaikkan harga-harga karena tingginya permintaan, sementara barang-barang tidak tersedia sehingga harganya naik. Inflasi tarikan permintaan (Demand Full Inflation) atau inflasi dari sisi permintaan (Demand side Inflation) adalah inflasi yang disebabkan karena adanya kenaikan permintaan agregat yang sangat besar dibandingkan dengan jumlah barang dan jasa yang ditawarkan

b. Inflasi karena dorongan biaya (Cost Push Inflation)

Yaitu inflasi karena biaya atau harga faktor produksi, seperti upah buruh meningkat sehingga produsen harus menaikkan harga supaya mendapatkan laba dan produksi bisa berlangsung terus. Inflasi desakan biaya (Cost push Inflation) atau inflasi dari sisi penawaran (Supply Side Inflation) adalah inflasi yang terjadi sebagai akibat dari adanya kenaikan biaya produksi yang pesat dibandingkan dengan tingkat produktifitas dan efisiensi, sehinnga perusahaan mengurangi supply barang dan jasa.

3. Berdasarkan asal Inflasi, Inflasi ini dapat dikategorikan kepada:

a. Domestik inflation

Yaitu Inflasi yang bersumber dari dalam negeri. Misalnya, Permintaan meningkat untuk barang tertentu, maka terjadi demand full inflation yang berasal dari dalam negeri.atau terjadi kenaikkan harga produksi yang diimpor, maka terjadi cost push inflation yang bersumber dari luar negeri atau impor cost push inflation.

b. Foreign atau imortet inflation

Yaitu inflasi yang bersumber dari luar negeri. Misalnya, terjadi lonjakan ekspor secara terusmenerus, maka terjadi demand Full inflation yang berasal dari luar negeri atau terjadi kenaikkan harga, factor produksi yang diimpor, maka terjadi cost push inflation yang bersumber dari luar negeri atau importet cost push inflation.

4. Berdasarkan harapan masyarakat, Inflasi dapat dikategorikan menjadi 2 yaitu:

a. Expected Inflation

Yaitu besar inflasi yang diharapkan atau diperkirakan terjadi. Misalnya, Bila inflasi dari tahun 2001 sampai 2006 konstan $6 \%$, kemudian akan ditanya berapa perkiraan mengenai 


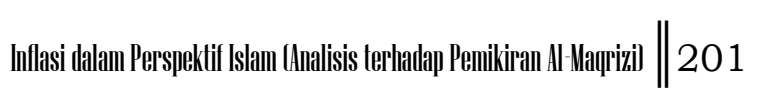

besarnya inflasi tahun 2007 maka tentunya akan dijawab $6 \%$.

b. Unexpected inflation

Yaitu inflasi yang tidak diperkirakan akan terjadi. Misalnya, diperkirakan inflasi 2007 sebesar $6 \%$, kemungkinan besar inflasi tahun 2007 menyimpang dari $6 \%$. Penyimpangan tersebut merupakan unexpected inflation. (Rozalinda, 2014: 304-306)

\section{TEORI INFLASI ISLAM}

Menurut para ekonom Islam, inflasi sangat berakibat buruk bagi perekonomian karena:

1. Menimbulkan gangguan terhadap fungsi uang, terutama terhadap fungsi tabungan (nilai simpan), fungsi dari pembayaran dimuka, dan fungsi dari unit penghitungan. Orang harus melepaskan diri dari uang dan aset keuangan akibat dari beban inflasi tersebut. Inflasi juga telah mengakibatkan terjadinya inflasi kembali atau dengan kata lain selffeding inflation.

2. Melemahkan semangat menabung dan sikap terhadap menabung dari masyarakat (turunnya marginal propensity to save).

3. Meningkatkan kecendrungan untuk berbelanja terutama untuk non primer dan barng barang mewah (naiknya marginal propensity to consume).

4. Mengarahkan investasi pada hal-hal yang non produktif yaitu penumpukan kekayaan (hoarding seperti tanah, bangunan, logam mulia, mata uang asing dengan mengorbankan investasi kearah produktif seperti pertaniaan, industrial, perdagangan, transportasi, dan lainnya. (Karim, 2011: 13)

\section{SEJARAH INFLASI}

Byzantium berusaha keras untuk mengumpulkan emas dengan melakukan ekspor komoditasnya sebanyak mungkin ke negara-negara lain dan berusaha mencegah impor dari negara-negara lain agar dapat mengumpukan uang emas sebanyak-banyaknya. Tetapi yang terjadi pada akhirnya orang-orang harus makan, membeli pakaian, mengeluarkan biaya transportasi, serta juga menikmati hidup sehingga mereka akan membelanjakan uang (kekayaan) yang dikumpulkannya tadi sehingga akhirnya malah menaikkan tingkat harga komoditasnya sendiri. Spanyol setelah era 'conguistadores' juga mengalami hal yang sama, begitu juga dengan inggris setelah perang dengan napoleon (napoleonic war). Awal inflasi mata uang dinar dimulai bahkan pada saat ketika Irak sedang dalam masa puncak jayanya. Revolusi Harga di Eropa terjadi sepanjang beberapa Abad, pola kenaikan tingkat harga pertama kali tampak di Italia dan Jerman sekitar tahun 1470 (mengikuti wabah Black Death pada tahun 1349). Kemudian Inflasi menyerang Eropa dalam Beberapa tahapan, dimulai dari Inggris dan Perancis pada tahun 1480-an, meluas ke semenanjung Iberia pada dekade selanjutnya dan menyerang Eropa Timur pada tahun 1500-an. Kenaikan tingkat harga sangat cepat pada bahan-bahan mentah terutama makanan. Di inggris harga kayu, ternak dan bijibijian meningkat sampai 5 - 7 kali lipat dari tahun 1480 sampai tahun 1650, sementara itu barang manufaktur 
harganya meningkat 3 kali lipat. Kenaikan sebesar $700 \%$ selama 170 tahun itu juga dihitung secara Compound hanya sebesar $1,2 \%$ pertahunnya, akan tetapi dilain sisi, gaji hanya meningkat kurang dari $1 / 2-n y a$, sehingga masyarakat sangat mengalami goncangan akibat tekanan inflasi. Daya beli uang dan gaji menurun dengan tingkat yang di anggap sangat mencemaskan. Semuanya adalah akibat gabungan dari penurunan produksi pertanian, pajak yang berlebih, depopulasi, manipulasi pasar, high labor cost, pengangguran, kemewahan yang berlebihan, dan sebabsebab lainnya, seperti perang yang berkepanjangan, embargo, dan pemogokan pekerja. (Karim, 2011: 133-134). Pada tahun 1870, Perancis juga mengalami Inflasi. Diduga ada hubungan besar antara kenaikan tingkat Inflasi dengan kenaikan produksi Emas. Menurut Michael Chevalier (seorang ekonom Perancis pada abad ke-19), pada tahun 1859 mengatakan bahwa pertambahan penawaran emas akibat ditemukannya tambang-tambang emas baru sehingga mengakibatkan. turunnya harga emas relatif yang akan membawa pada turunnya nilai riil emas (inflasi) atau naiknya tingkat harga seluruh barang kecuali emas. (Naf'an, 2014: p)

\section{PENYEBAB INFLASI DAN INDIKATOR INFLASI}

\section{Natural Inflation dan Human Error Inflation}

Natural Inflation adalah inflasi yang terjadi karena sebab-sebab alamiah yang manusia tidak mempunyai kekuasaan dalam mencegahnya. Natural inflation dapat dibedakan berdasarkan penyebabnya, yaitu : a. Akibat uang yang masuk dari luar negeri terlalu banyak, dimana ekspor $(\mathrm{X} \uparrow)$ sedangkan impor $(\mathrm{M} \downarrow)$ sehingga net export nilainya sangat besar, maka mengakibatkan naiknya Permintaan Agregatif (AD $\uparrow)$

Contoh : Pada masa khalifah Umar ibn Khattab, kafilah pedagang yang menjual barangnya di luar negeri membeli barang-barang dari luar negeri lebih sedikit nilainya daripada nilai barang-barang yang mereka jual, sehingga mereka mendapat keuntungan. Keuntungan yang berupa kelebihan uang tersebut dibawa masuk ke Madinah sehingga pendapatan dan daya beli masyarakat akan naik (AD $\uparrow)$. Naiknya Permintaan Agregat akan membuat kurva AD bergeser ke kanan dan akan mengakibatkan naiknya tingkat harga secara keseluruhan $(\mathrm{P} \uparrow)$. Kemudian, yang dilakukan oleh Umar ibn Khattab dalam mengatasi masalah tersebut adalah beliau melarang penduduk Madinah untuk membeli barangbarang selama 2 hari berturut-turut. Akibatnya, adalah turunnya Permintaan Agregat (AD $\downarrow)$ dan tingkat harga menjadi normal.

b. Akibat dari turunnya tingkat produksi (AS $\downarrow$ ) karena terjadinya panceklik, perang, ataupun embargo. Contoh Pada saat pemerintahan Umar ibn Khattab pernah terjadi masa panceklik yang mengakibatkan kelangkaan gandum, diibaratkan pada gravik sebagai kurva AS yang bergeser ke kiri (AS $\downarrow$ ) yang mengakibatkan naiknya harga-harga $(\mathrm{P} \uparrow)$. Yang dilakukan oleh Umar ibn Khattab dalam mengatasi permasalahan 


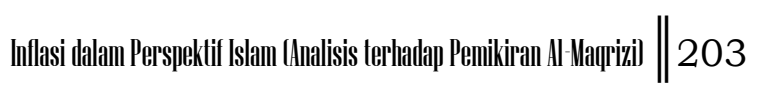

ini, beliau melakukan impor gandum dari Mesir, sehingga Penawaran Agregat (AS) barang di pasar kembali naik (AS $\uparrow$ ) yang kemudian berdampak pada penurunan hargaharga $(\mathrm{P} \downarrow)$. Human Error Inflation adalah Inflasi yang terjadi karena kesalahan-kesalahan yang dilakukan oleh manusia iu sendiri. Inflasi yang disebabkan oleh Human Error Inflation terjadi karena:

1) Corruption and Bad Administration (Korupsi dan Buruknya Administrasi)

Pengangkatan para pejabat yang berdasarkan suap, nepotisme, dan bukan kapabilitas akan menempatkan orang-orang berbagai jabatan penting dan terhormat yang tidak mempunyai kredibilitas. Mereka yang mempunyai mental seperti ini, rela menggadaikan seluruh harta milik untuk meraih jabatan, kondisi ini juga berpengaruh ketika mereka berkuasa, para pejabat tersebut akan menyalahgunakan kekuasaannya untuk meraih kepentingan pribadi, baik untuk menutupi kebutuhan finansial maupun keluarga atau demi kemewahan hidup. Akibatnya akan terjadi penurunan drastis terhadap penerimaan dan pendapatan negara.

2) Excessive Tax (Pajak yang tinggi)

Akibat dari banyaknya pejabat pemerintahan yang bermental korup, pengeluaran negara mengalami peningkatan yang sangat drastis, sebagai kompensasi mereka menerapkan sistem perpajakan tinggi dan menerapkan berbagai jenis pajak. Konsekuensinya biaya-biaya produksi meningkat, dan akan berimplikasi pada kenaikan harga barang produksi.

3) Excessive signore (Percetakan uang berlebihan)

Ketika terjadi defisit anggaran baik sebagai akibat dari kemacetan ekonomi, maupun perilaku buruk para pejabat yang menghabiskan uang negara, pemerintah melakukan percetakan uang fulus secara besar-besaran. Akibatnya uang tidak lagi bernilai.

\section{Actual/Anticipated/Expected Inflation dan Unanticipated/Unexpected Inflation}

Pada saat Expected Inflation tingkat suku bunga pinjaman riil akan sama dengan tingkat suku bunga pinjaman nominal dikurangi inflasi atau secara notasi $\mathrm{r}_{\mathrm{t}}=\mathrm{R}_{\mathrm{t}-i i_{\mathrm{r}}} \mathrm{c}_{\mathrm{r}}$ sedangkan pada Unexpected Inflation tingkat suku bunga pinjaman nominal belum atau tidak merefleksikan kompensasi terhadap efek inflasi.

\section{Demand PulI Inflation dan Cost Push Inflation}

Demand Pull Inflation yaitu kenaikan harga-harga yang terjadi akibat kenaikan permintaan aggregate (AD) yang lebih besar daripada penawaran agregate (AS). Artinya, inflasi terjadi apabila pendapatan nasional lebih besar daripada pendapatan potensial. Cost Push Inflation yaitu inflasi yang disebabkan karena peningkatan harga akibat naik nya biaya-biaya. Apabila permintaan terhadap bahan baku melebihi penawarnnya, maka harga akan naik. 
Karena pabrik membayar lebih mahal atas bahan baku mereka menetapkan harga produk akhir yang lebih tinggi kepada pedagang dan pedagang menaikkan harga barang itu yang kemudian akan ditanggung oleh para konsumen (Huda, Dkk, 2008: 178-179). Indikator yang sering digunakan untuk mengukur tingkat inflasi adalah Indeks Harga Konsumen (IHK). Perubahan IHK dari waktu ke waktu menunjukkan pergerakan harga dari paket barang dan jasa yang dikonsumsi masyarakat. Indikator inflasi lainnya berdasarkan international best practice antara lain:

a. Indeks Harga Perdagangan Besar (IHPB). Harga Perdagangan Besar dari suatu komoditas ialah harga transaksi yang terjadi antara penjual/pedagang besar pertama dengan pembeli/pedagang besar berikutnya dalam jumlah besar pada pasar pertama atas suatu komoditas.

b. Deflator Produk Domestik Bruto (PDB) menggambarkan pengukuran level harga barang akhir (final goods) dan jasa yang diproduksi di dalam suatu ekonomi (negeri). Deflator PDB dihasilkan dengan membagi PDB atas dasar harga nominal dengan PDB atas dasar harga konstan.

\section{PENDEKATAN MAKRO SYARIAH DALAM MENGATASI INFLASI}

Pendekatan Islam dalam mengatasi inflasi, Islam mendorong pemerintah untuk melakukan kebijakan penanggulangan inflasi dengan cara:

1. Himbauan moral, dengan cara menghimbau masyarakat untuk hemat dalam berbelanja
2. Mendorong peningkatan produksi dalam negeri

3. Subsidi langsung kepada masyarakat, seperti BLT (Bantuan Langsung Tunai)

4. Perbaikan Infrastruktur, seperti jalan dan lainnya.

5. Membuat Regulasi (aturan) yang mendorong pertumbuhan ekonomi masyarakat kecil Inflasi yang terus menerus, apalagi yang cukup tinggi harus diatasi dengan mengambil kebijakan-kebijakan sebagai berikut:

6. Kebijakan Moneter (Suprayitno, 2005: p)

7. Kebijakan Fiskal

Kebijakan ini dilakukan oleh pemerintah sejalan dengan kebijakan moneter. Ada tiga cara yang dilakukan sebagai berikut:

a. Mengatur penerimaan dan pengeluaran pemerintah.

b. Menaikkan tarif pajak. Jika tarif pajak dinaikkan tentu uang yang dapat dibelanjakan oleh masyarakat semakin berkurang, sehingga harga akan menurun.

c. Mengadakan pinjaman pemerintah. Pelaksanaannya dapat dilakukan secara otomatis tanpa kompromi terlebih dahulu misalnya agar uang tidak terlalu banyak beredar.

8. Kebijakan Non Moneter cara ini bisa ditempuh dengan tiga cara, yaitu:

a. Menaikkan hasil produksi, sekalipun jumlah uang beredar bertambah.

b. Kebijaksanaan upah. Pemerintah menganjurkan kepada serikat-serikat buruh untuk tidak menuntut kenaikan upah selagi masih terjadi inflasi tanpa dibarengi dengan peningkatan produksi.

c. Pengawasan harga, agar harga barang tidak terlalu naik, 
pemerintah dapat melakukan pengawasan dan kalau perlu menetapkan harga. Langkah lain untuk mengatasi inflasi adalah dengan melakukan sanering yaitu dengan cara menurunkan nilai nominal rupiah (Karim, 2011: 190198).

\section{SEJARAH SINGKAT AL-MAQRIZI}

Nama lengkap Al-Maqrizi adalah Taqiyuddin Al-Abbas Ahmad bin Ali Abdil Qadir Al-Husaini, Ia lahir di Desa Barjuwan, Kairo pada tahun 766 H (1364$1365 \mathrm{M})$. Keluarganya berasal dari maqarizah sebuah desa yang terletak di kota Ba'lakbak. Oleh karena itu ia cendrung dikenal sebagai Al-Maqrizi. Suprayitno, 2005: p) Kondisi ekonomi ayahnya yang lemah menyebabkan pendidikan masa kecil dan remaja AlMaqrizi berada dibawah tanggungan kakeknya dari pihak ibu Hanafi ibnu Sa'igh seorang penganut mazhab Hanafi. Al-Maqrizi tumbuh berdasarkan mazhab ini. Setelah kakeknya meninggal dunia pada tahun $786 \mathrm{H}$ (1384 M), Al-Maqrizi beralih ke mazhab Syafi'i. bahkan dalam perkembangan pemikirannya, ia terlihat cendrung menganut mazhab Zhahiri (Abiding, 1979: p). Al-Maqrizi merupakan sosok yang sangat mencintai Ilmu. Sejak kecil ia gemar melakukan rihlah ilmiah. Ia mempelajari berbagai disiplin ilmu, seperti fiqih, hadits dan sejarah, dari para ulama' yang besar yang hidup pada masanya. Diantara tokoh terkenal yang sangat mempengaruhi pemikirannya adalah Ibnu Khaldun, seorang ulama' besar dan penggagas ilmu-ilmu social, termasuk ilmu ekonomi. Interaksinya dengan Ibnu Khaldun dimulai ketika Abu Al-iqrishad ini menetap di Kairo dan memangku jabatan hakim agung (Qadhi Al-Qudah) mazhab Maliki pada masa pemerintahan Sultan Barquq $(784-801 \mathrm{H})$.

Al-Maqrizi juga merupakan seorang Muhtasib (pengawas pasar, semacam kepala lembaga ombudsman, pent.) yang memiliki pengetahuan tentang kondisi ekonomi pada masanya dan juga seorang pengkritik keras pemerintahan Burji Mamluk. Ia menerapkan analisis Ibnu Khaldun dalam bukunya yang berjudul Ighatsah Al-Ummah bi Kasyfil Gummah (menolong rakyat dengan mengetahui sebab-sebab penyakitnya). Yaitu menentukan sebab-sebab yang menimbulkan krisis ekonomi di Mesir pada masa periode 806808. Ketika berusia 22 tahun, Al-Maqrizi mulai terlibat dalam berbagai tugas pemerintahan Dinasti Mamluk. Pada tahun $788 \quad \mathrm{H} \quad\left(\begin{array}{lll}1386 & \mathrm{M})\end{array}\right)$ Al-Maqrizi memulai kiprahnya sebagai pegawai di Diwan Al-Insya, semacam sekertariat Negara. Kemudian ia diangkat menjadi wakil Qadhi pada kantor hakim agung mazhab Syafi'i. khatib di Masjid Jamil AlHakim dan guru Hadits di Madrasah AlMuayyadah.

Pada tahun $791 \mathrm{H}$ (1389 M), Sultan Barquq mengangkat Al-Maqrizi sebagai Muhtasib di Kairo. Jabatan tersebut diembannya selama dua tahun. Pada masa ini Al-Maqrizi mulai banyak bersentuhan dengan berbagai permasalahan pasar, perdagangan, dan Mudharrabah. Sehingga perhatiannya terfokus pada harga-harga yang berlaku, asal-usul uang dan kaidah-kaidah timbangan. Pada tahun 811 H $(1408$ M), Al-Maqrizi diangkat sebagai pelaksana administrasi Waqaf di Qalanisiyah, sambil bekerja di 
rumah sakit An-Nuri, Damaskus. Pada tahun yang sama, ia menjadi guru hadis di Madrasah Asyrafiyyah dan Madrasah Iqbaliyyah. Kemudian Sultan Al-Malik AlNashir Faraj bin Barquq (1399-1412 M) menawarinya jabatan wakil pemerintah Dinasti Mamluk di Damaskus. Namun, tawaran ini ditolak Al-Maqrizi. Setelah sekitar 10 tahun menetap di Damaskus, Al-Maqrizi kembali ke Kairo, sejak itu ia mengundurkan diri sebagai pegawai pemerintah dan menghabiskan waktunya untuk ilmu. Pada tahun 834 H (1430 M), ia bersama keluarganya menunaikan ibadah haji dan bermukim di Mekah selama beberapa waktu untuk menuntut ilmu serta mengajarkan hadits dan menulis sejarah.Lima tahun kemudian, Al-Maqrizi kembali ke kampung halamannya, Barjuwan, Kairo. Di sini ia juga aktif mengajar dan menulis, terutama sejarah Islam, hingga terkenal sebagai seorang sejarawan besar pada abad ke-9 Hijriyah. Al-Maqrizi meninggal dunia di Kairo pada tanggal 27 Ramadhan $845 \mathrm{H}$ atau bertepatan dengan tanggal 9 Februari 1442 M.

\section{KARYA-KARYA AL-MAQRIZI}

Semasa hidupnya, Al-Maqrizi sangat produktif menulis berbagai bidang ilmu, terutama sejarah Islam. Lebih dari seratus buah karya tulis telah dihasilkannya, baik berbentuk buku kecil maupun besar. Buku-buku kecilnya memilki urgensi yang khas serta menguraikan berbagai macam ilmu yang tidak terbatas pada tulisan sejarah. Al-Syayyal mengelompokkan buku-buku kecil tersebut menjadi empat kategori. Pertama, buku yang membahas beberapa peristiwa sejarah Islam umum, seperti kitab Al-Niza' wa Al-Takhshum fi ma baina Bani Umayyah wa Bani Hasyim. Kedua, buku yang berisi ringkasan sejarah beberapa penjuru Dunia Islam yang belum terbahas oleh para sejarawan lainnya, seperti Kitab Al-Imam bi Akhbar Man bi Ardh Al-Habasyah min Muluk AlIslam. Ketiga, buku yang menguraikan Biografi singkat para raja, seperti Kitab Tarajim Muluk Al-Gharb dan Kitab Al-Zahab Al-Masbuk bi Dzikr Man bi Hajja min AlKhulafa wa Al-Muluk. Keempat, buku yang mempelajari beberapa aspek ilmu murni atau sejarah beberapa aspek social dan ekonomi di Dunia Islam pada umumnya, dan di Mesir pada khususnya, seperti kitab Syudzur Al-'Uqud fi Dzikir AlpNuqud, kitab Al-Akhyal wa Al-Auzan Al-Syar'iyyah, kitab risalah fi Al-Nuqud Islamiyyah dan kitab Ighatsah Al-Ummah bi Kasyfil Gummah.

Sedangkan terhadap karya-karya AlMaqrizi yang berbentuk buku besar, AlSyayyal membagi menjadi tiga kategori. Pertama, buku yang membahas tentang sejarah dunia, seperti Khabar 'an Al-Basyr. Kedua, buku yang menjelaskan sejarah Islam umum, seperi kitab Ad-durar AlMudh'iyah fi Tarikh Al-Daulah AlIslamiyah. Ketiga, buku yang menguraikan sejarah Mesir pada masa Islam, seperti Kitab Al-Muwa'izh wa Al-I'tibar bi Dzikr AlImmah Al-Fahimiyyin Al-Khulafa, dan kitab Al-Suluk li Ma'rifah Duwal Al-Muluk. Dari sumber yang lain menyatakan bahwa Ramadhan al-Badri dan Ahmad Mushtafa Qasim telah mengkaji dan mengedit setidaknya ada 11 risalah Al-Maqrizi yang dibukukan dalam buku bertitel Rasa il AlMaqrizi yaitu: (Chamid, 2010: p)

Risalah Pertama, tentang pertentangan antara Bani Umayyah dan Bani Hasyim. Dalam risalah ini Al-Maqrizi menjelaskan tentang pertikaian antara kabilah Bani Umayyah dengan Bani Hasyim.Di sini Al- 
Maqrizi juga memaparkan bagaimana Rasulullah saw memberikan kekuasan wilayah Makkah, Madinah dan Hadramaut kepada Bani Umayyah. Di samping itu, dengan gaya bahasa yang sangat indah Al-Maqrizi menguraikan kebengisan Abu al-Abbas, pendiri khilafah Abbasiyah, yang dijuluki as-Saffah (orang yang banyak mengalirkan darah). Risalah Kedua, tentang kemurnian tauhid. Al-Maqrizi membeberkan berbagai perbedaan mendasar antara tauhid dan syirik. Menurutnya, inti dari ketauhidan adalah melihat bahwa segala sesuatu itu dari Allah dan mengabaikan lain-Nya, menyembah-Nya dengan sepenuh hati dan tidak menyembah selain-Nya. Hal ini berarti mengandung larangan untuk mengikuti hawa nafsu, sebab setiap orang yang mengikuti hawa nafsunya maka dengan serta merta ia menjadikan hawa nafsu sebagai sesembahannya. Kemudian AlMaqrizi memaparkan tentang dua macam syirik yang menimpa kebanyakan umat, yaitu syirik ilahiyyah dan rububiyyah. Syirik ilahiyyah inilah yang umumnya dilakukan orang-orang musyrik, seperti menyembah berhala, malaikat, jin, dan orang-orang yang dianggap suci. Disamping itu juga Al-Maqrizi menjelaskan syiriknya kalangan Qadariyah, dan mengarahkan pandangan-pandangan Qadariyah dan Jabariyah dengan santun dan argumentatif.

Risalah Ketiga, tentang kabilahkabilah badui yang ada di Mesir. Dalam risalah ini juga dikemukan tentang berbagai kabilah atau suku, klan, trah dan marga. Al-Maqrizi juga mengungkapkan dengan gaya bahasa yang indah mengenai macam-macam nama kabilah arab yang masih memiliki harta benda sampai sekarang di propinsi Mesir mulai dari utara sampai selatan. Di samping itu AlMaqrizi juga mengisahkan dengan alur sejarah yang indah tentang bagaimana kedatangan mereka dari jazirah Arab ke tanah Arab pada umumnya dan Mesir secara khusus. Risalah Keempat, tentang mata uang pada zaman dulu. Dalam hal ini, al-Baladiri dengan risalah-nya yang berjudul an-Nuqud telah mendahului AlMaqrizi. Risalah ini mengungkap tentang mata uang kuno yang berlaku pada awalawal Islam, kekhilafahan Islam dan Abbasiyah. Al-Maqrizi juga menjelaskan dirham baghli dan dirham jawaz. Menurut penuturan Al-Maqrizi, dirham baghli adalah mata uang yang berlaku di Persia. Disamping itu juga dijelaskan pengertian istilah awqiyyah, rithl, daniq, dan qirath. Menurut al-Maqirzi, setiap khalifah mencetak mata uang, seperti apa yang dilakukan oleh khalifah Usman bin Affan dengan mencetak mata uang dirham yang berlogo tulisan Allahu Akbar.

Risalah Kelima, tentang keutamaan keluarga Nabi dengan disertai dalildalilnya, baik dari Alquran maupun Hadis. Dalam risalah ini Al-Maqrizi juga melakukan perbandingan antara ayat-ayat Alquran dan tafsirnya yang diambil dari berbagai sumber-sumber tafsir yang otoritatif seperti al-Qurthubi dan Ibn Athiyah. Disini terlihat kepiawaian AlMaqrizi menyodorkan kepada para pembacanya tentang ragam pendapat para ahli tafsir kenamaan. Risalah Keenam, tentang berbagai hal kimiawi. Diantara yang dijelaskan didalam risalah ini adalah mengenai metal atau unsur kimiawi yang berat. Diantaranya ialah emas, perak, tembaga, timah, besi, dan seng. Dalam 
risalah ini terlihat bagaimana dengan bagusnya Al-Maqrizi menjabarkan unsurunsur kimiawi sehingga ia nampak sebagai seoarang ahli kimia handal. Risalah Ketujuh, tentang raja-raja Islam di Habsyi. Dalam risalah ini, Al-Maqrizi juga menjelaskan tentang negeri Habsyi. Di antara yang masuk ke dalam wilayah Habsyi ialah Zaila yang dibagi menjadi tujuh kerajaan, di antaranya adalah kerajaan Aufat, Hadiyyah, dan Daroh. Di samping itu dalam risalah ini kita akan melihat penjelasan secara tidak langusng mengenai kata bithriq (pemimpin para uskup) dan kata hathiyy dalam bahasa Habsyi yang sama dengan kata sulthan dalam bahasa Arab. Hal lain yang dijelaskan dalam risalah ini ialah penjelasan mengenai aliran yang ada di Habsyi, seperti al-Yaqubiyyah dan alMalakiyyah. Risalah Kedelapan, tentang menggebugebunya jiwa-jiwa yang mengutamakan dzikir. Risalah ini tergolong sangat pendek, tetapi isinya begitu menggugah jiwa. Bagi Al-Maqrizi orang yang utama adalah orang yang selalu atau melanggengkan dzikir.

Risalah Kesembilan, tentang akhir yang baik (Husn al-khatimah). Risalah Kesepuluh, tentang teka-teki air. Dan yang terakhir Risalah Kesebelas, tentang lebah. Inilah risalah yang sangat bagus dan banyak menarik berbagai kalangan untuk mempelajarinya. Dalam risalah ini AlMaqrizi menjelaskan bagaimana lebah yang bagus, sifat-sifatnya dan namanamanya, serta macam-macam madu. Semua risalah yang ditulis Al-Maqrizi menunjukkan bahwa ia adalah orang yang banyak mengetahui banyak hal. Dengan kata lain Al-Maqrizi adalah salah satu intektual Muslim yang multidimensi. Al-Maqrizi tidak hanya menguasai pengetahuan keagamaan, tetapi ia juga mengusai dengan baik pengetahuan nonkeagamaan atau pengetahuan umum. Tidak banyak pada zamannya intektual yang banyak menguasai berbagai disiplin ilmu pengetahuan seperti Al-Maqrizi. Dengan membaca risalah-risalahnya maka dapat menyelami kedalaman ilmu al Maqrizi.

\section{PEMIKIRAN EKONOMI AL-MAQRIZI TENTANG UANG.}

Al-Maqrizi berada pada fase kedua dalam sejarah pemikiran ekonomi Islam, sebuah fase yang mulai terlihat tandatanda melambatnya berbagai kegiatan intelektual yang inovatif dalam dunia Islam. Latar belakang kehidupan AlMaqrizi yang bukan seorang sufi atau filsuf dan relatif didominasi oleh aktivitasnya sebagai sejarawan Muslim sangat mempengaruhi corak pemikirannya tentang ekonomi. Ia senantiasa melihat setiap persoalan dengan Flash Back dan mencoba memotret apa adanya mengenai fenomena ekonomi suatu Negara dengan memfokuskan perhatiannya pada beberapa hal yang mempengaruhi naik turunnya suatu pemerintahan. Hal ini berarti bahwa pemikiran-pemikiran ekonomi Al-Maqrizi cenderung positif, suatu hal yang unik dan menarik pada fase kedua yang notabene didominasi oleh pemikiran yang normatif. Al-Maqrizi merupakan pemikir ekonomi Islam yang melakukan study khusus tentang uang dan inflasi. Fokus perhatian Al-Maqrizi terhadap dua aspek yang dimasa pemerintahan Rasulullah dan Al-Khulafa Al-Rasyidin tidak menimbulkan masalah, ini tampaknya dilatarbelakangi oleh semakin banyaknya penyimpangan nilai-nilai Islam, terutama 
dalam kedua aspek tersebut, yang dilakukan oleh para kepala pemerintahan Bani Umayyah dan selanjutnya (Karim, 2000: p).

Pada masa hidupnya, Al-Maqrizi dikenal sebagai seorang pengkritik keras kebijakan-kebijakan moneter yang diterapkan pemerintahan Bani Mamluk Burji yang dianggapnya sebagai sumber malapetaka yang menghancurkan perekonomian Negara dan masyarakat Mesir. Perilaku para penguasa Mamluk Burji yang menyimpang dari ajaran-ajaran agama dan moral telah mengakibatkan krisis ekonomi yang sangat parah yang didominasi oleh kecenderungan inflasioner yang semakin diperburuk dengan merebaknya wabah penyakit menular yang melanda Mesir selama beberapa waktu. Situasi tersebut menginspirasi AlMaqrizi untuk mempresentasikan berbagai pandangannya terhadap sebab-sebab krisis dalam sebuah karyanya kitab Ighatsah Al-Ummah bi Kasyfil Gummah. Dengan berbekal pengalaman yang memadai sebagai seorang muhtasib (pengawas pasar), Al-Maqrizi membahas permasalahan inflasi dan peranan uang didalamnya, sebuah pembahasan yang sangat menakjubkan di masa itu karena mengkorelasikan dua hal yang sangat jarang dilakukan oleh para pemikir Muslim maupun barat. Dalam karyanya tersebut, Al-Maqrizi ingin membuktikan bahwa inflasi yang terjadi pada periode 806-808 $\mathrm{H}$ adalah berbeda dengan inflasi yang terjadi pada periode-periode sebelumnya sepanjang sejarah Mesir (Chamid, 2010: 56). Dari perspektif objek pembahasan, apabila ditelusuri kembali berbagai literature Islam klasik, pemikiran terhadap uang merupakan fenomena yang jarang diamati para cendikiawan Muslim, baik pada periode klasik maupun pertengahan. Menurut survey Islahi, selain Al-Maqrizi, diantara sedikit pemikir muslim yang memiliki perhatian terhadap uang pada masa ini adalah Al-Gazali, Ibnu Taimiyyah, Ibnu Al-qayyim AlJauziyah dan Ibnu Khaldun. Dengan demikian, secara kronologis dapat dikatakan bahwa Al-Maqrizi merupakan cendekiawan Muslim abad pertengahan yang terakhir mengamati permasalahan tersebut, sekaligus mengkorelasikannya dengan peristiwa inflasi yang melanda suatu negeri.

Al-Maqzi adalah salah seorang murid Ibnu Khaldun yang terkemuka. Meskipun pada zaman rasulullah dan khulafaur Rasyidin uang dan inflasi tidak menimbulkan masalah sama sekali, tetapi dengan berjalannya waktu, banyak kepala pemerintahan yang meninggalkan nilainilai Islam sebagaimana yang dicontohkan Rasulullah. Akibatnya, kasus semacam ini menjadi masalah serius. Dalam hal ini dapat dilihat contoh kasus, sistem anggaran deficit, pada zaman Rasulullah, hal tersebut hanya satu kali dilakukan, yaitu sebelum perang hunain, itupun dibayar lunas setelah perang usai. Bandingkan dengan zaman Wazir (Perdana Mentri) Ibnu Furat (908-911) atau Ali bin Isa (912-916) ketika deficit anggaran dilakukan dengan meminjam dari bankir-bankir Yahudi dan Nasrani dalam jangka panjang. Sehingga terlihat perbedaan pola hidup Rasulullah dan para sahabat dibandingkan dengan kehidupan para Wazir di zaman Abbasyiah yang mempunyai simpanan ratusan ribu dinar di Bankir Yahudi dan Nasrani. Begitu juga halnya dengan mata 
uang yang digunakan pada zaman Rasulullah mulai ditinggalkan dan diganti dengan fulus yang dikenalkan oleh Sultan Kamil Ayyubi, dan diteruskan oleh Barquq yang mencetak fulus dengan jumlah yang besar demi mengambil keuntungan. Hal inilah yang menyebabkan Al-Maqrizi mengkritisi pemerintah pada saat itu.

Uang Islam secara resmi dan penuh pertama kali diterbitkan dalam bentuk dinar dan dirham Islam pada masa Khalifah Bani Umayah, Abdul Malik bin Marwan. Pada saat itu dinar dan dirham dicetak sesuai dengan timbangan yang telah ditentukan oleh Rasulullah. Sebelumnya Khalifah Umar pernah menerbitkan dirham, namun karena masih bercampur dengan unsur Persia maka tidak bisa disebut uang islam. Sampai saat ini, dinar dan dirham menjadi identik dengan Islam, padahal yang pertama menggunakan bukanlah umat Islam. Secara umum, ada perbedaan pendapat dintara fuqaha tentang keharusan penggunaan dinar dan dirham oleh umat Islam sebagai mata uang dalam perkonomian. Pendapat pertama menyatakan bahwa uang adalah bentuk penciptaan dan hanya terbatas pada dinar dan dirham. Artinya, tidak ada bentuk mata uang lain yang boleh dipergunakan selain dinar dan dirham, termasuk juga uang kertas yang beredar saat ini. Karena menurut mereka Allah telah menciptakan emas dan perak sebagai tolak ukur nilai. Sebagai buktinya adalah banyaknya istilah emas dan perak yang disebut dalam Alquran. Pendapat ini dikemukakan oleh Al-Ghazali, Ibnu Qudamah, dan Al-Maqrizi. Dikatakan oleh Maqrizi, "Sesungguhnya uang yang menjadi harga barang-barang yang dijual dan nilai pekerjaan adalah hanya emas dan perak saja. Tidak diketahui dalam riwayat yang shahih maupun yang lemah dari umat manapun dan kelompok manusia manapun, bahwa mereka dalam masa lalu dan masa kontemporernya selalu menggunakan uang selain keduanya".

Pendapat kedua menyatakan bahwa uang adalah masalah terminologi. Maka segala sesuatu yang secara terminologi manusia dapat diterima dan diakui oleh mereka sebagai tolak ukur nilai, maka bisa disebut sebagai uang. Pandangan ini lebih dekat dengan definisi uang yang ada saat ini. Pendapat ini juga menyepakati substansi dari pernyataan Umar r.a sebagai berikut: "Aku ingin menjadikan dirham dari kulit unta" Lalu dikatakan kepadanya, "Jika demikian, unta akan habis" maka dia manahan diri. Hal ini menunjukkan bahwa pemimpin dapat uang dari materi apapun dan dengan bentuk apapun selama dapat merealisasikan kemaslahatan, dan tidak menyalahi aturan syariah. Pendapat kedua ini didukung oleh Imam Malik, Imam Ahmad, Ibnu Taimiyah, dan Ibnu Hazm. Syaikhul Islam Ibnu Taimiyah mengatakan bahwa uang kembali pada terminologi manusia bahwa sesuatu itu adalah uang, dan ia beragam bentuknya sesuai keragaman tradisi dan adat istiadat manusia; dan beliau menafikan adanya uang yang pasti dengan hukum sya'i atau hukum alami (penciptaan). Dalam hal ini uang kertas yang banyak beredar saat ini secara fiqih dapat dinyatakan sebagai uang selama dalam terminologi manusia masih disebut uang.

Perbedaan pendapat ini tidak hanya terkait lahiriah dan fisik dari uang itu sendiri, tapi lebih jauh adalah pada halhal yang substansial (misal:posisi zakat 
dan riba). Hal ini mengingat bahwa uang memiliki peranan yang sangat penting; pelayanan besar yang diberikan oleh uang dalam perekonomian, hubungan yang kuat antara uang dan perekonomian, pengaruh uang yang sangat besar, dan uang merupakan salah satu faktor kekuasaan dan kemandirian ekonomi. Sebagai seorang sejarawan, Al-Maqrizi menyatakan beberapa pemikiran tentang uang melalui penelaahan sejarah mata uang yang digunakan oleh manusia. Pemikirannya ini meliputi sejarah dan fungsi uang, implikasi penciptaan mata uang buruk dan daya beli uang. Inilah konsep uang menurut Al-Maqrizi:

\section{SEJARAH DAN FUNGSI MATA UANG}

Bagi Al-Maqrizi, mata uang mempunyai peranan yang sangat penting dalam kehidupan ummat manusia, karena dengan menggunakan uang, manusia dapat memenuhi kebutuhan hidup serta memperlancar aktivitas kehidupannya. Oleh karena itu untuk membuktikan validitas premisenya terhadap permasalahan ini, ia mengungkapkan sejarah penggunaan mata uang oleh ummat manusia, sejak masa dahulu kala hingga masa hidupnya yang berada di bawah pemerintahan dinasti Mamluk. Menurut Al-Maqrizi, baik pada masa sebelum maupun setelah kedatangan Islam, mata uang digunakan oleh manusia untuk menentukan berbagai harga barang dan biaya tenaga kerja. Untuk mencapai tujuan ini, mata uang yang dipakai hanya terdiri dari emas dan perak.

Dalam sejarah perkembangannya, Al-Maqrizi menguraikan bahwa bangsa Arab jahiliyyah menggunakan dinar emas dan dirham perak sebagai mata uang mereka yang masing-masing diadopsi dari romawi dan Persia serta mempunyai bobot dua kali lebih berat dimasa Islam. Setelah Islam datang, Rasulullah Saw menetapkan berbagai praktik muamalah yang menggunakan kedua mata uang tersebut, bahkan mengkaitkannya dengan hukum zakat harta. Penggunaan kedua mata uang ini terus berlanjut tanpa perubahan sedikitpun hingga tahun $18 \mathrm{H}$ ketika khalifah Umar ibnu Al-Khattab menambahkan lafaz-lafaz Islam pada kedua mata uang tersebut. Perubahan yang sangat signifikan terhadap mata uang ini terjadi pada tahun $76 \mathrm{H}$. Setelah berhasil menciptakan stabilitas politik dan keamanan, khalifah Abdul Malik ibnu Marwan melakukan reformasi moneter dengan mencetak dinar dan dirham Islam. Penggunaan kedua mata uang ini terus berlanjut, tanpa perubahan yang berarti, hingga pemerintahan Al-Mu'tashim, Khalifah terakhir dinasti Abbasyiah (Chapra, 2000: p).

Dalam pandangan Al-Maqrizi, kekacauan mulai terlihat ketika pengaruh kaum mamluk semakin kuat di kalangan istana, termasuk terhadap kebijakan percetakan mata uang dirham campuran. Pencetakan fulus, mata uang yang terbuat dari tembaga, dimulai pada masa pemerintahan Dinasti Ayyubiyah, Sultan Muhammad Al-Kamil ibnu Al-Adil AlAyyubi, yang dimaksudkan sebagai alat tukar terhadap barang-barang yang tidak signifikan dengan rasio 48 fulus untuk setiap dirhamnya. Pasca pemerintahan Sultan Al-kamil, percetakan mata uang tersebut terus berlanjut hingga pejabat ditingkat provinsi terpengaruh laba yang besar dari aktivitas ini. Kebijakan sepihak 
mulai diterapkan dengan meningkatkan volume percetakan fulus dan menetapkan rasio 24 fulus perdirham. Akibatnya rakyat menderita kerugian yang besar karena barang-barang yang dahulu berharga setengah dirham sekarang menjadi satu dirham. Keadaan ini semakin memburuk ketika aktivasi pencetakan fulus meluas pada masa pemerintahan Al-Adil Kitbugha dan Sultan Al-Zahir Barquq yang mengakibatkan penurunan nilai mata uang dan kalangan barang-barang. Ibnu Khaldun menegaskan bahwa kekayaan suatu negara tidak ditentukan oleh banyaknya uang di negara itu, tapi ditentukan oleh tingkat produksi negara tersebut dan neraca pembayaran yang positif. Bisa saja suatu Negara mencetak uang sebanyakbanyaknya tapi bila hal itu tidak mencerminkan pesatnya pertumbuhan sektor produksi, uang yang melimpah itu tidak ada nilainya. Pendapat ini menunjukkan bahwa pola perdagangan internasional telah menjadi bahasan utama para ulama ketika itu. Negara yang telah mengekspor berarti mempunyai kemampuan berproduksi lebih besar dari pada kebutuhan domestiknya sekaligus menunjukkan bahwa negara tersebut lebih efisien dalam produksinya (Ibnu Khaldun).

Senada dengan Ibnu khaldun, Ibnu Taimiyyah menentang keras terjadinya penurunan nilai mata uang akibat dari pencetakan mata uang yang terlalu banyak. Ia menyatakan "Penguasa seharusnya mencetak fulus (mata uang selain emas dan perak) sesuai dengan nilai yang adil (proporsional) atas transaksi masyarakat, tanpa menimbulkan kezaliman terhadap mereka". Pernyataan tersebut memperlihatkan bahwa Ibnu Taimiyah memiliki beberapa pemikiran tentang hubungan antara jumlah uang, total volume transaksi dan tingkat harga. Pernyataannya tentang volume fulus harus sesuai dengan proporsi jumlah transaksi yang terjadi adalah untuk menjamin harga yang adil. Ia menganggap bahwa nilai intrinsic mata uang harus sesuai dengan daya beli di pasar sehingga kecil kemungkinan terjadinya jual beli uang.

Berbagai fakta sejarah tersebut menurut Al-Maqrizi mengidentifikasikan bahwa mata uang yang dapat diterima sebagai standar nilai, baik menurut hukum, logika maupun tradisi hanya yang terdiri dari emas dan perak. Oleh karena itu mata uang yang menggunakan bahan selain kedua logam ini tidak layak disebut sebagai mata uang. Lebih lanjut, ia menyatakan bahwa keberadaan fulus tetap diperlukan sebagai alat tukar terhadap barang-barang yang tidak signifikan dan untuk berbagai biaya kebutuhan rumah tangga sehari-hari. Dengan kata lain, penggunaan fulus hanya diizinkan dalam berbagai transaksi yang berskala kecil. Sementara itu walaupun menekankan urgensi penggunaan kembali mata uang yang terdiri dari emas dan perak, AlMaqrizi menyadari bahwa uang yang bukan merupakan satu-satunya faktor yang mempengaruhi kenaikan hargaharga. Menurutnya, penggunaan mata uang emas dan perak tidak serta merta menghilangkan inflasi dalam perekonomian karena inflasi juga dapat terjadi akibat faktor dalam dan tindakan sewenang-wenang dari penguasa. 


\section{IMPLIKASI PENCIPTAAN MATA UANG BURUK}

Al-Maqrizi menyatakan bahwa penciptaan mata uang dengan kualitas yang buruk akan melenyapkan mata uang yang berkualitas baik. Hal ini terlihat jelas ketika ia menguraikan situasi moneter pada tahun $569 \mathrm{H}$. Pada masa pemerintahan Sultan Shalahuddin Al-Ayyubi ini, mata uang yang dicetak mempunyai kualitas yang sangat rendah dibandingkan dengan mata uang yang telah ada di peredaran. Dalam menghadapi kenyataan tersebut, masyarakat akan lebih memilih untuk menyimpan mata uang yang berkualitas baik dan meleburnya menjadi perhiasan serta melepaskan mata uang yang berkualitas buruk ke dalam peredaran. Akibatnya mata uang lama akan kembali ke peredaran. Menurut Al-Maqrizi, hal tersebut juga tidak terlepas dari pengaruh pergantian penguasa dan dinasti yang masing-masing menerapkan kebijakan yang berbeda dalam pencetakan bentuk serta nilai dinar dan dirham. Sebagai contoh, jenis dirham yang telah ada diubah hanya untuk merefleksikan penguasa pada saat itu. Dalam kasus yang lain terdapat beberapa perubahan tambahan pada komposisi logam yang membentuk dinar dan dirham. Konsekuensinya terjadi ketidakseimbangan dalam kehidupan ekonomi ketika persediaan logam bahan mata uang tidak mencukupi untuk memproduksi sejumlah unit mata uang. Begitu pula halnya ketika harga emas atau perak mengalami penurunan. (Chapra, 2000: 128)

\section{KONSEP DAYA BELI UANG}

Menurut Al-Maqrizi, percetakan mata uang harus disertai dengan perhatian yang lebih besar dari pemerintah untuk menggunakan mata uang tersebut dalam bisnis selanjutnya. Pengabaian terhadap hal ini, sehingga terjadi peningkatan yang tidak seimbang dalam pencetakan uang dengan aktivitas produksi dapat menyebabkan daya beli riil uang mengalami penurunan. Dalam hal ini, Al-Maqrizi memperingatkan para pedagang agar tidak terpukau dengan peningkatan laba nominal mereka. Menurutnya mereka akan menyadari hal tersebut ketika membelanjakan sejumlah uang yang lebih besar untuk berbagai macam pengeluarannya. Dengan kata lain, seorang pedagang dapat terlihat memperoleh keuntungan yang lebih besar sebagai seorang produsen. Namun sebagai seorang konsumen, ia akan menyadari bahwa dirinya tidak memperoleh keuntungan sama sekali.

\section{TEORI INFLASI AL-MAQRIZI}

Dengan mengungkapkan berbagai fakta bencana kelaparan yang pernah terjadi di Mesir, Al-Maqrizi meyatakan bahwa peristiwa inflasi merupakan sebuah fenomena alam yang menimpa kehidupan masyarakat di seluruh dunia sejak masa dahulu hingga sekarang. Menurutnya terjadi ketika harga-harga secara umum mengalami kenaikan dan berlangsung terus-menerus. Pada saat ini persediaan barang dan jasa mengalami kelangkaan, dan karena konsumen sangat membutuhkannya, maka konsumen harus mengeluarkan lebih banyak uang untuk barang dan jasa yang sama.Dalam uraian berikutnya, Al-Maqrizi membahas permasalahan 
inflasi secara lebih mendetail. Ia mengklasifikasikan inflasi berdasarkan faktor penyebabnya ke dalam dua hal, yaitu inflasi yang di sebabkan oleh faktor alamiah dan inflasi yang disebabkan oleh kesalahan manusia.

\section{Inflasi Alamiah}

Sesuai dengan namanya, inflasi jenis ini disebabkan oleh berbagai faktor alamiah yang tidak bisa dihindari oleh manusia. Menurut Al-Maqrizi, ketika suatu bencana alam terjadi, berbagai bahan makanan dan hasil bumi lainnya mengalami gagal panen, sehingga persediaan barang-barang tersebut mengalami penurunan yang sangat drastis dan terjadi kelangkaan. Dilain pihak karena sifatnya yang sangat signifikan dalam kehidupan, permintaan terhadap berbagai barang tersebut mengalami peningkatan. Harga-harga membumbung tinggi jauh melebihi daya beli masyarakat. Hal ini sangat berimplikasi terhadap kenaikan harga berbagai barang dan jasa lainnya. Akibatnya, transaksi ekonomi mengalami kemacetan, bahkan berhenti sama sekali yang pada akhirnya menimbulkan bencana kelaparan, wabah penyakit dan kematian dikalangan masyarakat. Keadaan yang semakin memburuk tersebut memaksa rakyat untuk menekan pemerintah agar segera memperhatikan keadaan mereka. Untuk menaggulangi bencana itu, pemerintah mengeluarkan sejumlah besar dana yang mengakibatkan perbendaharaan negara mengalami penurunan drastis karena disisi lain pemerintah tidak mendapatkan pemasukan yang berarti. Dengan kata lain pemerintah mengalami deficit anggaran Negara baik secara politik, ekonomi, maupun sosial, dan menjadi tidak stabil yang kemudian menyebabkan keruntuhan sebuah pemerintahan. (Anto, 2010: p)

Lebih lanjut, ia menyatakan bahwa sekalipun suatu bencana telah berlalu, kenaikan harga-harga tetap berlangsung. Hal ini merupakan implikasi dari bencana alam sebelumnya yang mengakibatkan aktivitas ekonomi terutama di sektor produksi mengalami kemacetan. Ketika situasi lebih normal, persediaan barang-barang yang signifikan, seperti benih padi, tetap tidak beranjak naik, bahkan tetap langka, sedangkan permintaan terhadapnya meningkat tajam. Akibatnya, harga barang-barang ini mengalami kenaikan yang kemudian diikuti oleh kenaikan harga berbagai jenis barang dan jasa lainnya, termasuk upah dan gaji para pekerja.

\section{Inflasi Karena Kesalahan Manusia}

Selain faktor alam, Al-Maqrizi menyatakan bahwa inflasi dapat terjadi akibat kesalahan manusia. Ia telah mengidentifikasi tiga hal yang menyebabkan terjadinya inflasi jenis kedua ini yaitu: korupsi dan administrasi yang buruk, pajak yang berlebihan dan peningkatan sirkulasi mata uang fulus.

\section{Korupsi dan Administrasi yang Buruk.}

Al-Maqrizi menyatakan bahwa pengangkatan para pejabat pemerintahan yang berdasarkan pemberian suap dan bukan karena kapabilitas, akan menempatkan orang-orang yang tidak memiliki kredibilitas pada jabatan penting dan terhormat baik dikalangan legislatif, yudikatif, maupun eksekutif. Mereka rela menggadaikan seluruh harta miliknya sebagai kompensasi untuk meraih jabatan yang diinginkan serta kebutuhan sehari-hari sebagai pejabat. 
Akibatnya para pejabat pemerintahan tidak lagi bebas dari intervensi dan intrik para kroni istana. Mereka bukan hanya disigkirkan setiap saat, tetapi juga disita kekayaannya, bahkan dieksekusi. Kondisi ini selanjutnya sangat mempengaruhi moral dan efisiensi administrasi sipil dan militer. Ketika berkuasa, para pejabat tersebut mulai menyalah gunakan kekuasaan untuk meraih kepentingan pribadi, baik untuk memenuhi kewajiban finansialnya maupun kemewahan hidup. Mereka berusaha mengumpulkan harta sebanyak-banyaknya dengan menghalalkan segala cara. Merajalelanya ketidakadilan para pejabat tersebut telah membuat kondisi rakyat semakin memprihatinkan, sehingga mereka terpaksa meninggalkan kampung halaman dan pekerjaannya. Akibatnya terjadi penurunan drastis jumlah penduduk dan tenaga kerja serta hasil-hasil produksi yang sangat berimplikasi terhadap penurunan penerimaan pajak dan pendapatan Negara (Amalia, 2005: p).

\section{Pajak Yang Berlebihan}

Menurut Al-Maqrizi akibat dominasi para pejabat bermental korup dalam suatu pemerintahan, pengeluaran Negara megalami peningkatan yang sangat drastis. Sebagai kompensasinya, mereka menerapkan system perpajakan yang menindas rakyat dengan memberlakukan berbagai pajak baru serta menaikkan tingkat pajak yang telah ada. Hal ini sangat mempengaruhi kondisi para petani yang merupakan kelompok mayoritas dalam masyarakat. Para pemilik tanah yang ingin selalu berada dalam kesenangan akan melimpahkan beban pajak kepada para petani melalui peningkatan biaya sewa tanah, sehingga tekanan para pejabat dan para pemilik tanah terhadap petani menjadi lebih besar dan intensif. Frekuensi berbagai pajak untuk pemeliharaan bendungan dan pekerjaan- pekerjaan yang serupa semakin meningkat, konsekuensinya biaya-biaya untuk penggarapan tanah, penaburan benih, pemungutan hasil panen dan sebagainya meningkat. Dengan kata lain, panen padi yang dihasilkan pada kondisi ini membutuhkan biaya yang lebih besar hingga melebihi jangkauan para petani.

Kenaikan harga-harga tersebut terutama benih padi hampir mustahil mengalami penurunan karena sebagian besar benih padi dimiliki oleh para pejabat yang sangat haus kekayaan Akibatnya para petani kehilangan motivasi untuk bekerja dan memproduksi. Mereka lebih memilih meninggalkan tempat tinggal dan pekerjaannya daripada harus hidup dalam penderitaan untuk kemudian menjadi pengembara di daerah-daerah pedalaman. Dengan demikian, terjadi penurunan jumlah tenaga kerja dan peningkatan lahan tidur yang akan mempengaruhi tingkat hasil produksi serta hasil bumi lainnya, dan pada akhirnya menimbulkan kelangkaan bahan makanan serta meningkatnya harga-harga.

\section{Peningkatan Sirkulasi Mata Uang Fulus}

Seperti yang telah disinggung diatas, pada awalnya mata uang fulus yang mempunyai nilai intrinsik jauh lebih kecil dibandingkan dengan nilai nominalnya dicetak sebagai alat transaksi untuk memenuhi berbagai 
kebutuhan hidup sehari-hari yang tidak signifikan. Oleh sebab itu jumlah mata uang ini sangat sedikit yang terdapat dalam peredaran. Ketika terjadi deficit anggaran sebagai akibat dari prilaku buruk dari para pejabat yang menghabiskan uang Negara untuk berbagai kepentingan pribadi dan kelompoknya, akhirnya pemerintah melakukan pencetakan uang fulus secara besar-besaran. Menurut AlMaqrizi, kegiatan tersebut semakin meluas pada saat ambisi pemerintah untuk memperoleh keuntungan yang besar dari pencetakan mata uang yang tidak membutuhkan biaya produksi yang tinggi sehingga semakin tidak terkendali. Sebagai penguasa, mereka mengeluarkan maklumat yang memaksa masyarakat untuk menggunakan mata uang itu. Jumlah fulus yang dimiliki masyarakat semakin besar dan sirkulasinya mengalami peningkatan yang sangat tajam sehingga fulus menjadi mata uang yang dominan (Karim, 2002: p).

Lebih jauh, Al-Maqrizi menyatakan bahwa kebijakan pemerintah tersebut berimplikasi terhadap keberadaan mata uang yang lainnya. Seiring dengan keuntungan besar yang diperoleh dari pencetakan fulus, pemerintah menghentikan pencetakan perak sebagai mata uang. Bahkan sebagai salah satu implikasi gaya hidup para pejabat, sejumlah dirham yang dimilki oleh masyarakat dilebur menjadi perhiasan. Sebagai hasilnya, mata uang dirham mengalami kelangkaan dan menghilang dari peredaran, sementara itu mata uang dinar masih terdapat dalam peredaran meskipun hanya dimilki oleh beberapa gelintir orang. Keadaan ini menempatkan fulus sebagai standar nilai bagi sebagian besar barang dan jasa. Kebijakan pencetakan fulus secara besar-besaran menurut Al-Maqrizi sangat mempengaruhi penurunan nilai mata uang secara drastis. Akibatnya uang tidak lagi bernilai dan harga-harga membumbung tinggi yang pada gilirannya menimbulkan kelangkaan bahan makanan.

\section{DAFTAR KEPUSTAKAAN}

Anto, Andri. 2010. Pengantar ekonomi Makro Islam, Yogyakarta: ekonisia

Amalia, Euis. 2005. Sejarah Pemikiran Ekonomi Islam dari Masa Klasik Hingga Kontemporer. Jakarta: Pustaka Asatrus.

Abiding, Zainal. 1979. Dasar-Dasar Ekonomi Islam, Jakarta: Bulan Binang.

Budiono. 2005. Ekonomi Makro, Jogyakarta: BPFE UGM.

Chapra, Umar. 2000. Sistem Moneter Islam, Gema Insani, Press

Chamid, Nur. 2010. Jejak Langkah Sejarah Pemikiran Ekonomi Islam, Jogyakarta: Pustaka Pelajar.

Huda, Nurul, Dkk. 2008. Ekonomi Makro Islam. Jakarta: Prenada Media Group.

Karim, Adiwarman. 2011. Ekonomi Makro Islam, Jakarta: PT Raja Grafindo. Edisi ketiga.

Karim, Adiwarman. 2000. Sejarah Pemikiran Ekonomi Islam, Jakarta: Raja Grafindo Persada.

Naf'an. 2014. cet 1. Ekonomi Makro: Tinjauan Ekonomi Syari'ah. Yogyakarta: Graha Ilmu 
Murni, Asfia. 2006. Ekonomi Makro, Bandung: PT Rafika aditama

Rozalinda. 2014. Ekonomi Islam. Jakarta: Raja Grafindo Persada.

Suprayitno, Eko. 2005. Ekonomi Islam (Pendekatan Ekonomi Makro Islam dan Konvensional), Yogyakarta: Graha Ilmu.
Sukirno, Sadono. 2008. Pengantar Teori Makro Ekonomi. Jakarta: PT Raja Grafindo Persada

Karim, Ediwarman. 2002. Ekonomi Islam Suatu Kajian Ekonomi Makro, Jakarta: The International Institute of Islamic thought Indonesia 